\title{
Anatomical Characterization on the Leaf of Cayratia pedata var. glabra (Lam.) Gagnep. var. glabra Gamble (Vitaceae) - An Endemic Climber of Western Ghats, India
}

\author{
S. Sharmila* and K. Kalaichelvi \\ PG and Research Department of Botany, Vellalar College for Women, Thindal, Erode - 638012, Tamil Nadu, India; \\ drsharmilas@yahoo.com
}

\begin{abstract}
In the present effort an endeavor has been made to observe the various morphological and anatomical investigations on the leaf of Cayratia pedata var. glabra, belongs to the family Vitaceae. This is used in Ayurveda, Folk and Siddha medicine for the treatment of ulcer, antiseptic, antidiarrhoeal, refrigerant and cough. Anatomical studies revealed the presence of unicellular, non glandular epidermal trichomes, three abaxial horizontal bundles and one adaxial median bundle, anomocytic stomata and parenchymatous cells with calcium oxalate crystals. It helps to recognize and standardize the crude drug for medicinal uses. Presence of bilobed fruit is the important differentiable characterization among the other genus.
\end{abstract}

Key words: Anatomy, Anomocytic, Cayratia pedata var. glabra, Macerate, Medicinal plant, Morphology

\section{Introduction}

Homogeny of herbal medicines and superiority control of the plant raw materials are very important aspects of manufacture and supply of herbal drugs. The significance of herbals is realized and efforts are being made to satisfy the regulatory requirements. Drug plants were extensively described by Aristotle and Theophrastus, as early in $77 \mathrm{BC}$. The WHO [1] has brought out guidance for the assessment of herbal medicine for public health care in developing nations and progress guidelines to support and formulate national policies for the member states in their efforts on traditional medicine and to study potential usefulness including evaluation, safety and efficacy [2]. However, there is a great stumbling block in promoting the use of herbal drugs and boosting export of herbal products. The lack of scientific evaluation and standardization, uncertainty in the detection of medicinal plants and their substitutes, adulteration and lack of legitimate and reliable scientific information for their healing efficacy are some of the major problems encountered [3].

Cayratia pedata var. glabra is a climber of the family Vitaceae (Figure 1). The local name of the species is 'Kattuppirandai'. This is endemic and endangered species in southern India. The species Cayratia is distributed in tropical and subtropical areas. The genus Cayratia consists of 63 species [4]. The whole plant of Cayratia pedata var. glabra is used for treating diuretic, acrid, refrigerant and beneficial in hysteria, burning of the skin and diarrhoea $[5,6]$. The decoction of leaves checks uterine and other fluxes. Leaf juice is used as ear drops for fungal infections [7]. Cayratia pedata var. glabra is being pharmacologically and chemically screened for its medicinal properties recently $[8,9]$. However, pharmacognostical work is lacking in this plant. Hence, the present work aimed to attempt morphological and anatomical characterization on the leaf of C. pedata var glabra.

${ }^{*}$ Author for correspondence 


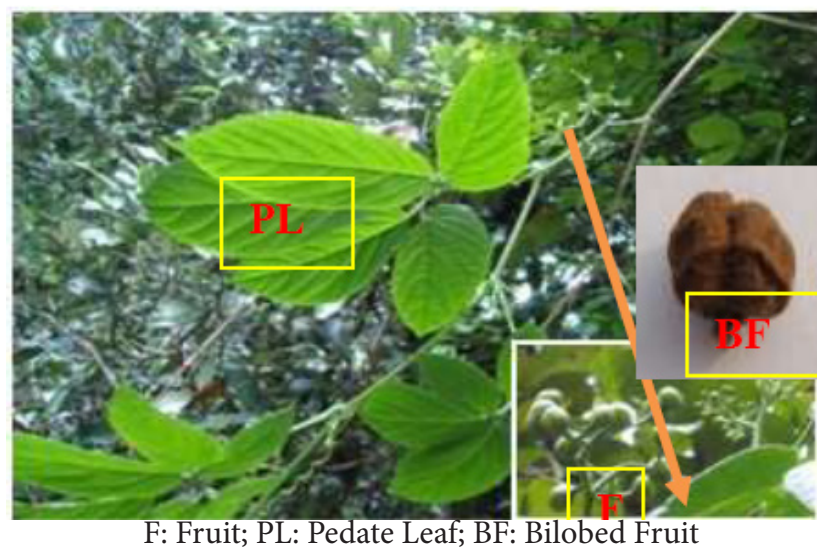

Figure 1. The flowering twig and enlarged fruiting twig of Cayratia pedata var. glabra.

\section{Materials and Methods}

The plant of Cayratia pedata var. glabra were collected from Thiashola, Manjoor, Nilgiris South Division, Western Ghats and the voucher herbarium specimen was preserved by standard methods [10]. The plant species is initially identified with the help of the existing local Floras [11-13] and the identity is authenticated by matched with type specimens available in the herbarium of Botanical Survey of India, Southern Circle, TNAU Campus, Coimbatore, Tamil Nadu. Morphological and anatomical studies were carried out as per the standard methods [14-16] during the year 2010.

The morphology and anatomy of the plant were carried out according to the method of $[17,18]$. Fresh leaves were alienated from the plant and methodically washed with running water to eliminate the adherent impurities. Some quantities of the leaves were air dried, powdered and stored in air-tight containers. Fresh leaves were used for the free hand section cutting with the help of safety-razor blade. Fresh leaves were fixed in FAA and dehydrated with TBA as per the schedule [19]. Addition of paraffin waxes in section, statured the TBA, in this time the specimens were cast into paraffin blocks. The paraffin embedded specimens were sectioned with the help of Rotary Microtome. Dewaxing of the sections was done by customary procedure [14]. The sections were stained with Toluidine blue, Safranin and IKI - Lugol's iodine [20]. After clearing the Transverse Section of various anatomical studies were carried out from the specimen. Photographs of different magnifications (40x and 100x) were taken with NIKON ALPHA PHOTO-2 microscopic unit. Descriptive terms of the anatomical features are taken from the standard anatomy book ${ }^{21}$.

\section{Results and Discussion}

Botanical detection of a phytodrug involves two steps. One is identification of the plant by its floral characters and the other is diagnosis of the plant with its microscopic characters. The latter procedure is useful for identification of fragmentary plant specimens. Early plant morphologist Robert Hook [22] clearly demonstrated that each kind of plant has its own distinctive structure by means of which it can be recognized.

\subsection{Morphological Studies}

The macroscopic characters of fresh aerial plant parts of C. pedata var. glabra are presented in Table 1 . The plant $C$. pedata var. glabra is an herbaceous, large, fragile climber grows up to a height of 8-12 m with nodes and internodes. Terminal buds of plants develop into tendrils. The present morphological investigations revealed that the stem is hirsute and grows up to a height of $12 \mathrm{~m}$. The leaves are alternate, pedately lobed, lobes oblong and acuminate with smooth surface and texture. The size is 3 to $6 \mathrm{~cm}$. The stem and leaves showed characteristic odour and bitter taste. Several earlier workers have described morphological features as one of the effective parameters for the pharmacognostical identification of crude drugs $[23,24]$.

Table 1. Macroscopic analysis of C. pedata var. glabra

\begin{tabular}{|c|c|}
\hline S.No. & Macroscopic characters \\
\hline 1. & $\begin{array}{l}\text { Stem: Hirsute } \\
\text { Height: Up to } 12 \mathrm{~m} \text { in height } \\
\text { Surface: Bearing distinct hairs } \\
\text { Texture: Smooth } \\
\text { Taste: Bitter } \\
\text { Odour: Characteristic } \\
\text { Colour: Dark green }\end{array}$ \\
\hline 2. & $\begin{array}{l}\text { Leaves: Alternate, pedately } 5 \text { foliolate, } 8-15 \mathrm{~cm} \text { long } \\
\text { Leaflets: Elliptic, oblong, apex acuminate, serrate } \\
\text { Number of leaflets: } 7-12 \\
\text { Size: } 3-6 \mathrm{~cm} \\
\text { Surface: Quite glabrous except on the veins } \\
\text { underneath } \\
\text { Texture: Smooth } \\
\text { Taste: Bitter } \\
\text { Odour: Characteristic } \\
\text { Colour: Dark green }\end{array}$ \\
\hline 3. & Tendril: Leaf opposed, branched, wiry, coiled \\
\hline 4. & Flowers: At first yellow later white \\
\hline 5. & Fruit: Berry, bilobed \\
\hline
\end{tabular}




\subsection{Anatomical Studies}

The present anatomical study provides a set of characters specific for C. pedata var. glabra with which one can establish the identity of the plant in fragmentary form. Free hand section of the leaf observed under the microscope revealed that the leaf has thick midrib and lateral veins and thin dorsiventral lamina. The midrib is characteristic with wide adaxial hump and wide semicircular abaxial part (Figure 2-2(a) and 2(b)). It is $1.15 \mathrm{~mm}$ thick; the adaxial part is $500 \mu \mathrm{m}$ in horizontal plane and 350 $\mu \mathrm{m}$ in height. The abaxial part is $1.2 \mathrm{~mm}$ wide. It consists of a thin and wavy epidermal layer of small, thin walled circular cells. The adaxial part has small, compact collenchymatous cells filling the entire ground tissue (Figure 3), remaining ground tissue consists of thin walled, angular parenchymatous tissue.

The vascular strands consist of three abaxial horizontal bundles and one adaxial median bundle. Of the three

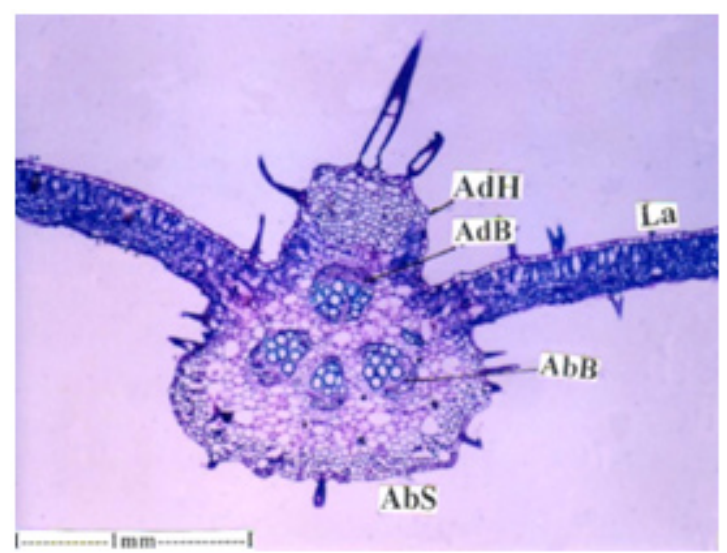

(a)

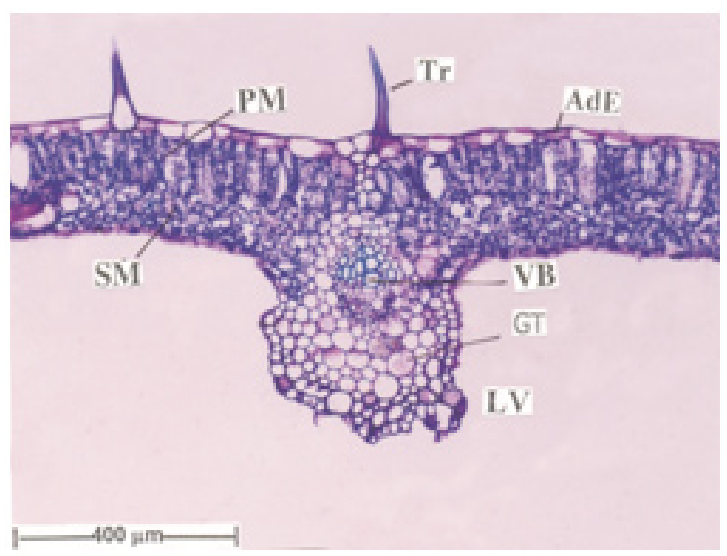

(b)

Figure 2. (a) T.S. of leaf through midrib. (b) T.S. of leaf through lateral view.

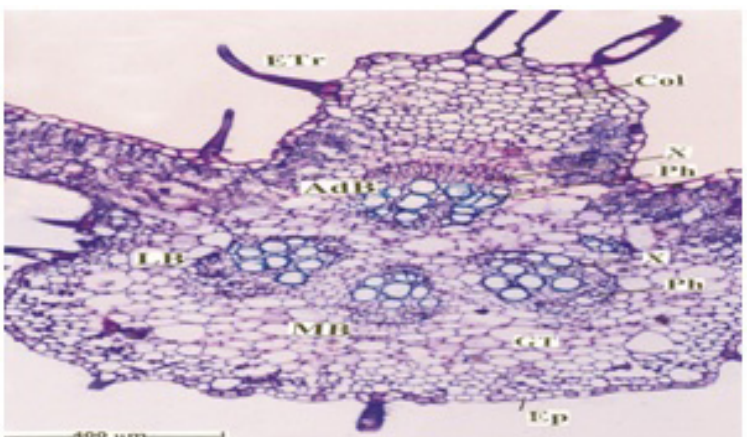

AbS: Abaxial Side; AbB: Abaxial Bundle; La: Lamina; AdB: Adaxial Bundle; AdH: Adaxial Hump; LB: Lateral Bundle; MB: Middle Bundle; X: Xylem; Ph: Phloem; GT: Ground Tissue; Ep: Epidermis; ETr: Epidermal Trichome; Col: Collenchyma

Figure 3. T.S of midrib - enlarged.

abaxial bundles, the median one is smaller and two lateral bundles are larger. The adaxial bundle is the largest one. All the bundles are collateral and consist of wide, circular, fairly thick walled xylem elements and thick rectangular segment of phloem. Epidermal trichomes of non glandular type are seen on the surface of the midrib. This is in corroboration with the work of Sutapa Choudry et al [6]. He studied the leaf epidermal micro morphology among three different species viz., Ampelocissus latifolia, Cayratia pedata and Cayratia trifolia. The investigation revealed that in each case, the epidermal cells of all the three species are irregular in shape, trichomes are non-glandular, crystals are needle in both the surfaces, stomata are of various types namely amphistomatic, hypostomatic and anomocytic types.

The lateral vein is plano-convex with flat adaxial side and prominently projecting abaxial part. It is $440 \mu \mathrm{m}$ thick and $300 \mu \mathrm{m}$ wide. It has thin epidermal layer of squarish cells and ground tissue of angular compact cells. The vascular strand is single, wedge/top shaped collateral with a few xylem elements in clusters and a cluster of phloem elements (Figure 2(b)). The lamina is distinctly dorsiventral having thick adaxial epidermis and thin abaxial epidermis. The adaxial epidermal cells are rectangular, thin walled with less prominent cuticle; the cells are 20-30 $\mu \mathrm{m}$ thick. The palisade tissue is single layered, the cells being narrowly cylindrical and less compact; they are $70 \mu \mathrm{m}$ in height. Calcium oxalate crystals of raphide type are fairly abundant in the palisade zone; the raphide bundles are vertical in position, parallel to the palisade cells (Figure $4-4(\mathrm{a})$ and 4(b)); they are $140 \mu \mathrm{m}$ long and $40 \mu \mathrm{m}$ thick. 


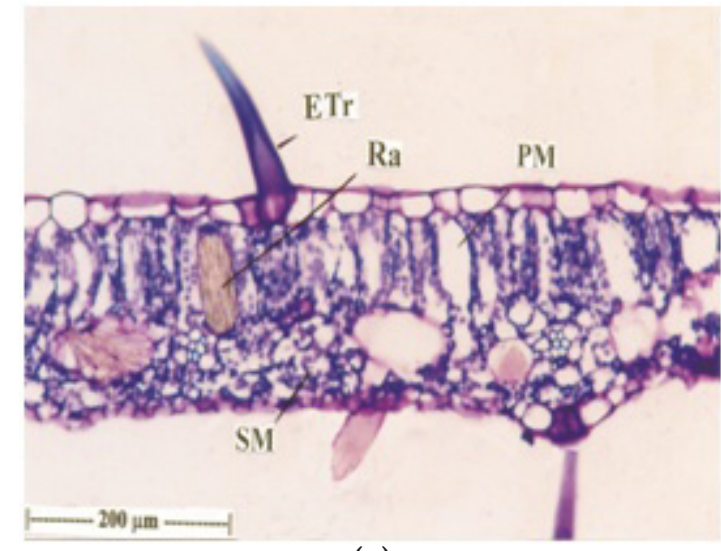

(a)

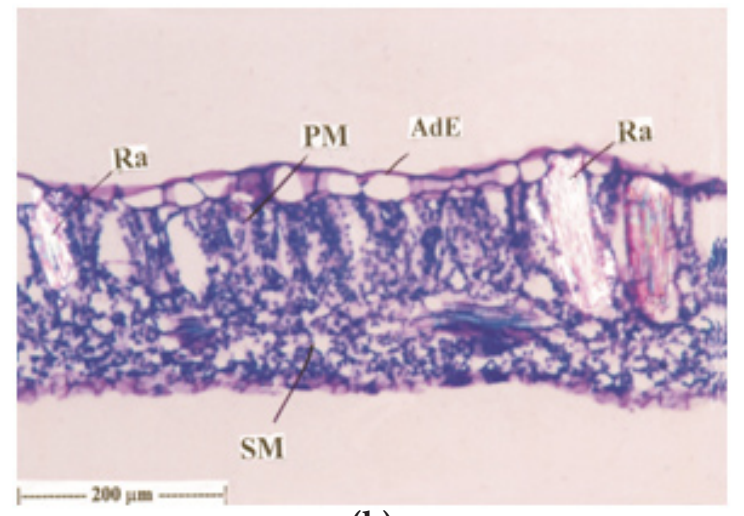

(b)

ETr: Epidermal Trichome; Ra: Raphide; PM: Palisade Mesophyll; SM: Spongy Mesophyll; AdE: Adaxial Epidermis

Figure 4. (a) T.S of lamina. (b) T.S of Lamina (Under polarized light microscope).

The adaxial epidermal cells are wide, angular and thick walled with slightly wavy anticlinal walls. The adaxial layer is apostomatic (Figure $5-5(a)$ and $5(b)$ ). The abaxial epidermis has smaller cells with thin walls and is more wavy. The stomata are anomocytic, having no specific subsidiary cells. The guard cells are circular measuring $15-20 \mu \mathrm{m}$ in diameter. The stomatal pore is distinct and elliptic (Figure 5(b)).

Calcium oxalate crystals are abundant in the mesophyll region, veins and trichomes. Druses or sphaero - crystals are seen in vertical rows within the veins (Figure $6-6(a)$ ). On the surface of the epidermal trichomes are seen as minute prismatic crystals in dense masses (Figure $6-6(\mathrm{~b})$ ). Raphides are thick cylindrical bundles of several needle shaped crystals aggregated together. They occur inside dilated cells which also contain mucilage (Figure 7 - 7(a)). In paradermal sections, the raphide is in horizontal plane, randomly

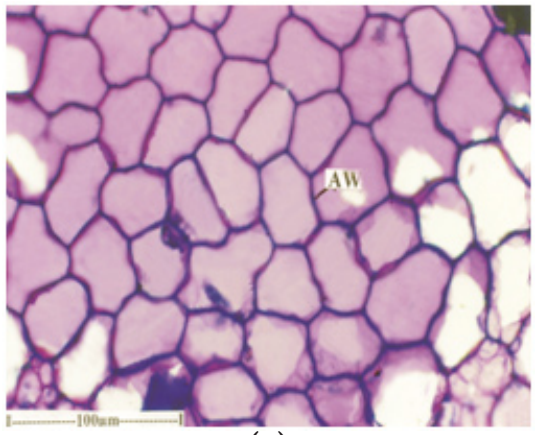

(a)

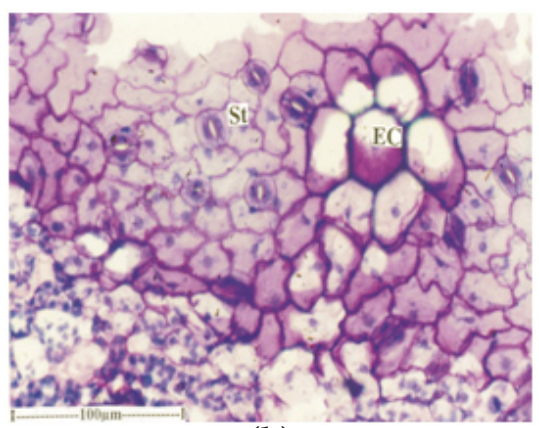

(b)

AW: Anticlinal Walls; St: Stomata; EC: Epidermal Cells

Figure 5. (a) Paradermal section of the adaxial epidermis. (b) Paradermal section of the abaxial epidermis with stomata.

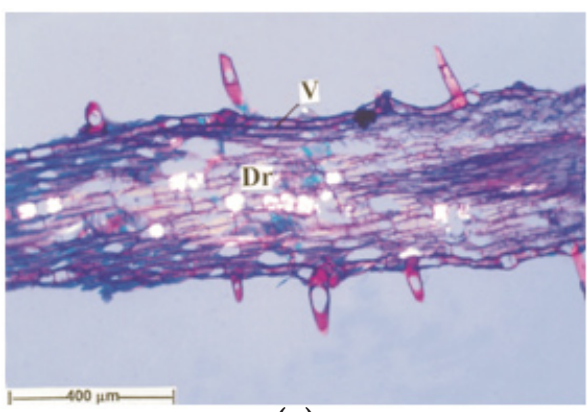

(a)

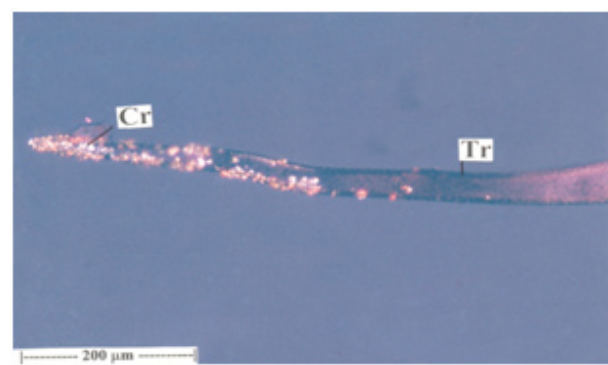

(b)

Dr: Druses; V: Vein Tr: Trichomes; Cr: Crystals Ra: Raphide

Fig 6. (a) L.S of a vein of the leaf showing distribution of calcium oxalate druses. (b) Epidermal trichome with minute crystals clinging on the surface 


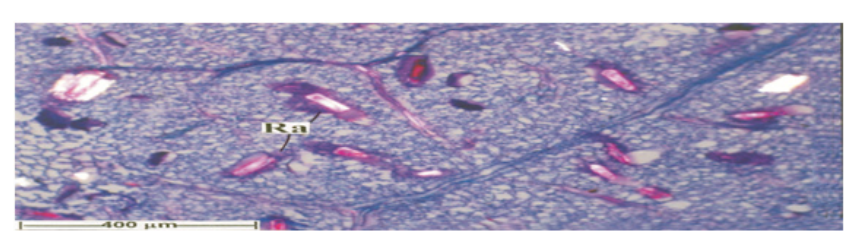

Figure 7. Raphides as seen in paradermal sections

oriented. Presence of raphides, calcium oxalate crystals and mucilage in the leaf powder is a unique diagnostic feature for the identification of crude drug of C. pedata var. glabra. It would be helpful to identify the drug and its purity.

\section{Conclusion}

The total summation of morphological features of C. pedata var. glabra coupled with anatomical parameters will furnish the protocol for pharmaceutical investigations. Various botanical, pharmacognostical and phytochemical parameters such as organoleptic tests and histochemical tests can be overcome the problems associated with the collection, identification and standardization of crude and raw drugs. Such a multi point analysis may help in the pharmacognostical standardization of $C$. pedata var. glabra that can check the intentional and unintentional adulteration, thereby enhancing the quality of a wide spectrum of medicinal preparations in which they form an active ingredient.

\section{References}

1. WHO 1991. In Progress Report by the Director General. Document No. A44/20, 22 ${ }^{\text {nd }}$ March 1991, World Health Organization; Geneva.

2. Rao EV. Scope of Plant Drugs in Modern Medicine. Visakha Sci J. 1997; 1:47.

3. Kumar D, Gupta J, Kumar S, Arya R, Kumar T, Gupta A. Pharmacognostic evaluation of Cayratia trifolia (Linn) leaf. Asian Pacific Journal of Tropical Biomedicine. 2012; 6-10.

4. Gamble JS, Fischer CEC. Flora of the Presidency of Madras; Calcutta. 1967. p. 1-3.

5. Abraham Z, Bhakuni DS, Garg HS, Goel AK, Mehrotra BN, Patnaik GK. Screening of Indian plants for biological activity. Part XII. Indian J Experi Biol. 1986; 24:48-68.

6. Singh MP, Panda H. Medicinal herbs with their formulations; 1994. p. 230.

7. Chakraborty MK, Bhattarcharjee A. Some common ethnomedicinal uses for various diseases in Purulia district, West Bengal. Indian J Tradi Knowledge. 2006; 5(4):554-8.
8. Choudhury S, Chowdhury HR, Mandal S. Studies on Foliar epidermal micromorphology and preliminary phytochemical screening of three medicinally important Taxa of the Family Vitaceae. Santiniketan: Department of Botany, Visva-Bharati; 2006.

9. Najmaddin C, Hussin K, Maideen H. Comparative anatomical study between Cayratia mollissima, Pterisanthes caudigera (Vitaceae) and Leea indica (Leeaceae). American Journal of Applied Sciences. 2011; 8 (9): 839-42.

10. Jain SK, Rao RR. Field and herbarium methods. New Delhi: Today and Tomorrow Publisher; 1977.

11. Fyson PF. The Flora of the Nilgiri and Pulney hill tops. Madras: Superintendent, Government Press; 1915-20.

12. Gamble JS, Fischer CEC. Flora of the Presidency of Madras. Calcutta: Botanical Survey of India; 1957.

13. Matthew KM. The Flora of the Tamil Nadu Carnatic. The Rapinet Herbarium. Tiruchirapalli: St Joseph's College; 1983. p. 278-9.

14. Johansen DA. Plant Microtechnique. Newyork: Mc Graw Hill Book Co; 1940. p. 523.

15. Wallis TE. Text book of Pharmacognosy. 5th ed. New Delhi, India: CBS Publishers and Distributors; 1985.

16. CameloSRP, Costa RS, de Pontes Vieira JG, Ribeiro-Costa RM, Barbosa WLR, Vasconcelos F, Silva Junior JOC. Anatomical characterization and Microchemistry of Vismia guianensis (aubl.) Choisy (Clusiaceae) blade leaf. International Journal of Pharmaceutical Sciences. 2012; 3(5):1312-7.

17. Johansen DA. Plant Microtechnique. Newyork: Mc Graw Hill Book Co; 1940. p. 523.

18. Wallis TE. Text book of Pharmacognosy. $5^{\text {th }}$ ed. New Delhi, India: CBS Publishers and Distributors; 1985.

19. Sass JE. Elements of Botanical Microtechnique. Newyork: McGraw Hill Book Co; 1940. p. 222.

20. O’Brien TP, Feder N, Mc Cull ME. Polychromatic staining of plant cell walls by toluidine blue-O. Protoplasma. 1964; 59:364-73.

21. Esau K. Plant Anatomy. Newyork: John Wiley and sons; 1964. p. 767.

22. Hook R. Micrographic or some physiological description of minute bodies made by magnifying glasses observations inquiries there upon. 1605-1703.

23. Lakshmi N, Jagadamma A. Pharmacognosy of Ayurvedic Drugs, Kerala. Thiruvananthapuram: Pharmacognosy Unit, Ayurvedic Research Institute; 1996. p. 165-72.

24. Rivera-Arce E, Gattuso M, Alvarado R, Zarate R, Aguero J, Feria I, Lozoya X. Pharmacognostical studies of the plant drug Mimosae tenuiflorae cortex. J Ethanopharmacol. 2007; 113:400-8. 